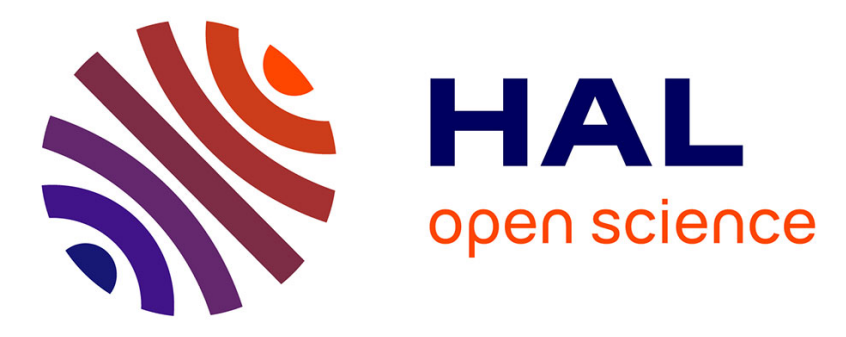

\title{
Cultural Transfer Theory and Exchanges between Britain and the Baltic in the Eighteenth Century
}

Rémy Duthille

\section{To cite this version:}

Rémy Duthille. Cultural Transfer Theory and Exchanges between Britain and the Baltic in the Eighteenth Century. Liina Lukas, Silke Pasewalck, Vinzenz Hoppe, Kaspar Renner. Medien der Aufklärung - Aufklärung der Medien. Die baltische Aufklärung im europäischen Kontext, De Gruyter Oldenbourg, pp.303-315, 2021, Medien der Aufklärung - Aufklärung der Medien. Die baltische Aufklärung im europäischen Kontext, 9783110712506 . hal-03444579

\section{HAL Id: hal-03444579 https://hal.science/hal-03444579}

Submitted on 23 Nov 2021

HAL is a multi-disciplinary open access archive for the deposit and dissemination of scientific research documents, whether they are published or not. The documents may come from teaching and research institutions in France or abroad, or from public or private research centers.
L'archive ouverte pluridisciplinaire HAL, est destinée au dépôt et à la diffusion de documents scientifiques de niveau recherche, publiés ou non, émanant des établissements d'enseignement et de recherche français ou étrangers, des laboratoires publics ou privés. 
Cultural transfer theory and Exchanges between Britain and the Baltic in the Eighteenth Century

This article reviews cultural transfer methodology as it was devised in the context of Franco-German research in the 1980s, and as it developed alongside other relational, transnational historiographies. Examining the historiography of relations between Britain and the Baltic (from Sweden to Russia) in the eighteenth century, if suggests that cultural transfers could complement current approaches and proposes avenues of research on the basis of books published in Riga.

La méthodologie des transferts culturels, élaborée dans un context franco-allemand dans les années 1980, s'est développée alors que d'autres historiographie transnationales montaient en puissance. L'article examine l'historiographie des relations entre la Grande-Bretagne et la Baltique au sens large au dix-huitième siècle. Ce domaine d'étude bénéficierait d'analyses en termes de transfert culturel, comme en témoignent des propositions de sujets possibles à partir d'ouvrage publiés à Riga.

Since its theoretical elaboration in the early 1980s, »cultural transfer « has become a current term in the present historiographical literature, especially when it comes to the study of eighteenth-century Germany and France. Such a development is in keeping with the global turn that was taken by research across the world as it has increasingly focused on exchanges and phenomena that cannot be understood within a purely national framework of analysis. This essay aims to give a critical perspective on some exchanges involving the Baltic region in the eighteenth century (in the broad sense of areas bordered by the Baltic Sea, encompassing the current Baltic states but also Sweden, Denmark, North German states and St Petersburgh), by rehearsing the methodology of cultural transfer, and discussing the historiography of relations between the Baltic and Britain, and especially Scotland, the part of Britain which had the most sustained and complex relations with the Baltic. The question of British-Baltic transfers has not been systematically tackled. However, exchanges were sustained and varied but they have been viewed through other historiographical prisms, which suggests that cultural transfer is still a potential critical tool for research in that area. A final section will present examples of possible research based on cultural transfer methodology. 
Cultural transfer methodology ${ }^{1}$ was defined in the early 1980s by French Germanists Michel Espagne and Michael Werner; the first theoretical formulations and case studies were carried out in the framework of the French national centre for scientific research CNRS. Werner and Espagne, and a group of scholars working on Heinrich Heine, were looking for the emergence of a »German cultural reference« in France in a long nineteenth century ranging from c. 1750 to the outbreak of the First World War. Their work involved tracing the translations, appropriations and acculturations that occurred in literature and the social sciences resulting in a German »memory « embedded in French archives and institutions. The cultural transfer approach went beyond the simple concern with influences, and was concerned with tracing the cultural intermediaries and the institutional and social milieus effecting transfers (in a sociological perspective), but also (in a philological perspective) the genesis and development of references to German culture in French discourses.

»Transfer« is a very simple word, chosen for its neutrality, any Freudian overtone being left aside. It involves a movement (real in the form of travelling or transport; or metaphorical e.g. like the act of reading a foreign writing). As Hartmut Kaelble notes: »Unter Transfers versteht Espagne die Wandlungen, die bei der Übertragung von Konzepten, Normen, Bildern und Repräsentationen von einer Kultur in die andere stattfinden. ${ }^{2}$ In the process the object transferred occupies a certain space and performs a given function in the receptor culture, which may accept or reject it. A transfer involves some transformation of the object; it is akin to a translation as the object's meaning will change in the receptor culture's semiotic system. Understanding culture as a multilayered semiological system serving as a communication network for the whole people, Espagne considers that transfers can be located at different levels, though the most visible and significant ones are the large literary-

\footnotetext{
1 This presentation is based on: Michel EsPaGNE: Les transferts culturels franco-allemands. Paris 1999 ; Wolfgang SCHMALE: Cultural Transfer, http://www.ieg-ego.eu/schmalew-2012-en ; Matthias MidDELL: »Kulturtransfer, Transferts culturels«, Docupedia-Zeitgeschichte, 2016. <http://docupedia.de/zg/Kulturtransfer〉

2 Hartmut KAELBLE: »Die Debatte über Vergleich und Transfer und was jetzt?«. In: Connections. A Journal for Historians and Area Specialists, 2005. <http://www.connections.clio-online.net/article/id/artikel-574>
} 
ideological constructions that give a national culture its identity and sense of itself. ${ }^{3}$ Hence studies of the adaptation of vast cultural fields of disciplines from one country to the other (anthropology, sociology...), or the reception of great authors - but Espagne also insists that such an emphasis on great men is insufficient and should be complemented by research on networks and micro-transfers in the realm of everyday life. ${ }^{4}$

Cultural transfer can be best approached through a concise yet rich definition given by a practitioner oft he theory, Matthias Middell: »Kulturtransfer wird verstanden als ein aktiv durch verschiedene Mittlergruppen betriebener Aneignungsprozess, der von den Bedürfnissen der Aufnahmekultur gesteuert wird. $\aleph^{5}$ As an acculturation process, cultural transfer implies that foreign elements are adopted over time and are transformed in the operation. The process involves a period of time, which can extend to years, decades or even centuries. Werner and Espagne argued against the simple ideas of diffusion and influence. It is mistaken, for instance, to argue that Louis XIV's absolutist model and its tools and symbols like Versailles simply diffused across Europe. Such a view of diffusion suggests the superiority of one culture over others. Whatever the princes may have thought of the superiority of Versailles, their cultural productions should be judged in their own terms without positing the superiority of the model, or the »original«, over the »copy«. The concept of influence is rejected because of its assumption of passivity on the part of the receptor culture, and because it presupposes that both cultures are given and static.

On the contrary, the adoption of external cultural elements has nothing automatic about it, but requires the active engagement of cultural intermediaries and an active process of adaptation on the part of members of the receptor culture; it happens »durch verschiedene Mittlergruppen « which are the second key element of Middell's definition. A rich literature has been devoted to such go-betweens, using various classical historiographical methods like biography or prosopography but also more innovative, digital tools of network analysis. The

ESPAGNE: Transferts (= Anm. 1), 18-19.

ESPAGNE: Transferts (= Anm. 1), 30.

MidDELL: »Kulturtransfer, Transferts culturels« (= Anm. 1). 
Republic of Letter, a time-hallowed, though disputed field, ${ }^{6}$ still provides a framework for such studies. The idea has received a new boost of critical attention through the study of those below (or behind) the »great men«, a host of translators, journalists, critics, reviewers, printers, newspaper owners - all those intermediaries whose unremitting work provided the infrastructure for the international exchanges of texts, ideas and practices. ${ }^{7}$ Two major projects are using digital technologies to map the numerous interlocking networks and provide visually stunning representations. »Mapping the Republic of Letters « [http://republicofletters.stanford.edu/], piloted by Stanford University, groups a cluster of studies of major philosophers (Voltaire, Locke, d'Alembert, Huyghens) undertaken by European universities and research institutions. The other major project, »Reassembling the Republic of Letters « is an EU cooperation project offering a »digital framework for multilateral collaboration on Europe's intellectual history (1500-1800)«. The websites enable a visualization of correspondence networks filtered by date, names, and other criteria, thus hopefully giving a clearer perception of intertwined, complex, shifting networks than research publications could give. ${ }^{8}$ However seductive and useful those digital initiatives might be when it comes to grasping certain complex realities and popularizing them, they cannot show causation and context-dependent processes of appropriation; but this is precisely what studies of cultural transfer can best provide.

Finally, to return to Middell's three-fold definition, transfers are driven by the needs of the receiving culture. The receptor context is key; it matters more than the goals or ambitions of would-be cultural exporters. A cultural entrepreneur may well try, but fail, to set up a venture abroad, publish a translation or register a patent; the fate of cultural products largely

6 The contours of the Republic of Letters are unclear and debated, the narrower German concept of »Gelehrtenrepublik« being favoured by some French scholars to delimit a » République des Sciences « inside the »République des Lettres«. See the introduction to a journal issue on the intermediaries of the Republic of Science: Irène PASSERON, René SigRist, Siegfried BoDEnMANN: »La République des sciences. Réseaux des correspondances, des académies et des livres scientifiques «. In: Dix-huitième siècle, 40 (2008), 5-27.

See e.g. a major prosopography, including famous figures like Leibniz and much lesser known actors : Les Grands Intermédiaires culturels de la République des Lettres: études de réseaux de correspondances du XVIe au XVIIIe siècles. Ed. Christiane BerkVEns-STEVElinck, Hans Bots, Jens HÄSElER. Paris, 2005. This is how the authors defined cultural intermediaries : »Für das Ancien Régime wird der kulturelle Vermittler als ein Mitglied der Gelehrtenrepublik definiert, der sich selber als Bindeglied zwischen unterschiedlichen kulturellen Einheiten sah, seien dies Nationen, Sprachen, Milieus, konfessionelle oder philosophische Räume« (quoted in Martin Stuber's review of the book in Schweizerische Zeitschrift für Geschichte, 59 (2009) 255).

${ }^{8} \mathrm{http}: / / \mathrm{ww}$.republicofletters.net/. A German-language presentation is available at:

http://www.hab.de/de/home/wissenschaft/forschungsprofil-und-projekte/reassembling-the-republic-of-letters.html 
escapes their originators' intentions as the adaptation of cultural or sociable institutions like clubs, salons, lodges or cafés, the fate of translations, and the multiple, surprising or contradictory uses of texts in other contexts can show. One of the implications is that failed transfers can be as illuminating as successful ones as they reveal much about the receptor culture through the untranslatability of some cultural products, the constraints on actors' agency, the social norms or the preconditions that must be met by networks and social capital for the success of a cultural transfer venture. ${ }^{9}$ The end product of a transfer is not simply an unchanged cultural item tacked into a receiving culture, but a hybrid product that serves an original purpose in that culture - unless the transfer was rejected, in which case the original product remains available for transfer.

Middell also details a sequence of adoption, starting by identification of the deficit in the receiving culture and ending with a recognition of the cultural transfer. The example he gives is that of the reform of French universities in the nineteenth century. The French authorities borrowed new forms of pedagogy, organization and management from German universities and set up a new system that looked much like the German one. When the cultural transfer was complete, several decades later, the French refused to acknowledge any debt to the German model, for reasons of national rivalry, and claimed they had set up their own, original model. This example is a particularly complete one because the cultural transfer was planned and its steps were visible and extremely well documented in the archives; it is also paradigmatic in the sense that it modelled national identities through the education system and the involvement of government and administration. However, there are many small-scale cultural transfers that do not follow the pattern entirely or have to be largely inferred. On the other hands, there are diffuse connections that extend over centuries, involve many intermediaries with sometimes overlapping, at times conflicting agendas, and that lack the clarity and purposefulness of a state-driven scheme like Middell's example.

While Espagne considered that the model was best applied to national groups, and therefore to periods posterior to the emergence of national identities (which he dated to the

9 See e.g. the multiple attempts of Scottish polymath William Playfair: Jean-François DuNYACH: »Les réseaux d'un excentrique: vies et parcours de William Playfair (1759-1823)«. In: Cultural Transfers: France and Britain in the Long Eighteenth Century. Ed. Ann Thomson, Simon Burrows, Edmond DzIEMBowski, Sophie AudidiÈRE. Oxford 2010 , p. 115-127. 
mid-eighteenth century), ${ }^{10}$ since the 1990 s cultural transfer methodology has been adopted in broader contexts, both in space and time. Espagne himself and researchers from the ex-GDR like Middell have looked at the infra-national level, i.e. local and regional cultures like Saxony or the links between Bordeaux, Hamburg and Hanseatic cities, still in the eighteenth and nineteenth century. ${ }^{11}$ As the demise of the Soviet Union facilitated collaborations with the former Eastern bloc, the Franco-German focus broadened to include Russia in 'triangular transfers'. ${ }^{12}$ Interest for Russia and the eastern reaches of the German-speaking world has sparked interest in the Baltic. Michel Espagne has chronicled the fate of Tartu, showing how the successive states it belonged to turned the city and its university them into a palimpsest of Swedish, German, and Russian heritage and memories, but also as an enclave of Germanspeaking research within the tsarist empire - a hybridity which gave Tartu a distinctive identity and a highly original position as a site of criticism over the centuries, including under Soviet rule. ${ }^{13}$ Beyond France, Germany and their immediate European neighbours, studies have focused on a multiplicity of colonial settings. In the process, the phrase »cultural transfer « has sometimes, but not always, been used in a loose sense, without reference to the original model, in studies of the impact of colonial migrations for instance. ${ }^{14}$

Michel Espagne claimed that the new approach of cultural transfer went »beyond « the established practice of comparatism, which, in his viewed, had to constitute national cultures (so that they could be compared in the first place), thus reifying cultures by ignoring some elements that were foreign (and precisely those elements were undergoing significant cultural transfer), finally yielding synchronic, snapshot views at the expense of the diachronic,

\footnotetext{
10 EsPagne: Transferts (= Anm. 1), 1-2, 17.

$11 \quad$ Von der Elbe bis an die Seine: Kulturtransfer zwischen Sachsen und Frankreich im 18. und 19. Jahrhundert. Ed. Michel Espagne, Matthias Middell. Leipzig 1993 ; Michel EsPagne : Bordeaux-Baltique : la présence culturelle allemande à Bordeaux aux XVIIIe et XIXe siècles. Paris 1991.

12 Transferts culturels triangulaires France-Allemagne-Russie. Ed. Katia DMITRIEVA, Michel EsPaGNE. Paris 1996. 13 Michel EsPagne : »Dorpat, Derbt, Juriew, Tartu : une Russie de langue allemande«. In : L'Ambre et le fossile: transferts germano-russes dans les sciences humaines XIXe - XXe siècles. Paris 2014, p. 37-52.

14 This is the case in: Ulster-New Zealand migration and cultural transfers. Ed. Brad PATTERSON. Dublin, Ireland; Portland, OR, 2006. On the other hand, see the special issue of Revue germanique internationale, which is critically informed by Espagne's and Werner's work and contains several articles on German perceptions of alterity, theories of métissage and translation, and studies of transfers to non-Western spaces, like: Sergei SEREBRIANY, »Le roman en Russie et en Inde. Deux cas de transfert d'un objet culturel occidental dans une culture non occidentale«. In : Revue germanique internationale 21 (2004), 149-162.
} 
dynamic appraisals of reality afforded by cultural transfer. ${ }^{15}$ Espagne's attacks prompted a lively debate among (mostly) German and French historians and Germanists, in party because he stated that comparatism led to a reinforcement of national histories. ${ }^{16}$ It is unlikely, however, that cultural transfers will supersede the practice of historical comparison. Outstanding comparative work such as Kenneth Pomeranz's study of the »great divergence« between the economies of China and Western Europe shows how useful the exercise of comparison remains, and how historians have rejected the most objectionable, Eurocentric, reifying aspects of the outdated method of comparative history (if ever there was one such method). ${ }^{17}$

Many historians focusing on transnational patterns have remedied the defects of traditional approaches without adopting cultural transfer theory; or rather, this theory could be presented, as Matthias Middell does, as »eine bemerkenswerte methodische Offenheit «, as a toolbox enabling many uses appropriate to the historical object considered. »Angesichts dieser wechselseitigen Stimulierung hat sich einerseits der Begriff des Kulturtransfers in das Repertoire einer kulturhistorischen Transnationalismus- und Globalisierungsforschung eingefügt. $\ll{ }^{18}$ Cultural transfer theory can thus be presented as a member of a family of relational histories alongside »global history« and »Atlantic history«, which are much more influential paradigms in English-speaking research. ${ }^{19}$ But, in a more critical, reflexive approach, Middell has also analyzed the conceptual and methodological relations between

\footnotetext{
$15 \quad$ Michel ESPAGNE : »Sur les limites du comparatisme en histoire culturelle«. In Genèses 17 (1994), 112-121 ; Michel ESPAGNE : »Au-delà du comparatisme«. In : EsPAGNE: Transferts (= Anm. 1), 35-49.

16 KAELBLE, » Die Debatte über Vergleich und Transfer und was jetzt? « (= Anm. 2).

Kenneth Pomeranz, The Great Divergence: China, Europe and the Making of the Modern World Economy. Princeton, NJ. 2000. Among many publications, see, on this debate: KAELBLE, »Die Debatte über Vergleich und Transfer und was jetzt? «(= Anm. 2).

18 MidDELL: »Kulturtransfer, Transferts culturels« (= Anm. 1).

19 Chloé MAUREL : »L'histoire transnationale, connectée, croisée, partagée«. In : Manuel d'histoire globale. Paris 2014, 49-78. There exist several good presentations of cultural transfer theory in French and German textbooks, but not, to the best of the author's knowledge, in English-language ones. See for instance: Hans-Jürgen LüSEBRINK: Interkulturelle Kommunikation: Interaktion, Fremdwahrnehmung, Kulturtransfer, 4., aktualisierte und erweiterte Auflage. Stuttgart 2016 ; Thomas KELLER: »Kulturtransferforschung: Grenzgange zwischen den Kulturen«. In: Kultur: Theorien der Gegenwart. Ed. Stephan MoEBIUs, Dirk QuADFLIEG. Wiesbaden 2006, 101-114. Conversely, cultural transfer is absent from Englishlanguage textbooks like The Oxford Handbook of World History. Ed. Jerry H. BENTLEY. Oxford 2013.
} 
cultural transfer and global history, pleading for a dialogue with yet other approaches (American studies of cultural encounters, postcolonial studies, métissage). ${ }^{20}$

Some cross-fertilization is under way the cultural transfer methodology is making its way into the field of British history and into research written in English more generally. Perhaps unsurprisingly, the earlier occurrences of the phrase »cultural transfer« came from scholars based in French or German, rather than British or American, universities. A paramount example is a collection of essays edited by Stefanie Stockhorst, who developed a methodological reflection on transfers in translation studies. ${ }^{21}$ French scholars also recently examined »cultural transfers in religion«, charting the wandering and adaptations of the Book of Common Prayer from the sixteenth to the eighteenth century. Another project traces the »travels « of the English Republic to various European countries, and the ideological, rhetorical and strategical changes that mid-seventeenth century English texts, symbols and figures underwent until the time of the French Revolution. ${ }^{22}$ Since the mid-2000s a number of studies have been published on the relations between Britain and France in the eighteenth century, trying to go beyond influential accounts in terms of antagonism (the long eighteenth century understood as the second Hundred Years' War; or Britishness stemming from rejection of France as an alien Other). ${ }^{23}$ The generally prevailing state of war between Britain and France (and much of the continent) in the eighteenth century hamstrung or slowed exchanges, but never entirely blocked them; conversely, war encouraged some forms of interactions and perhaps even, as Stephen Conway claims, transnational ways of thinking.

20 Matthias MIDDELL : »Histoire universelle, histoire globale, transfert culturel «. In Revue germanique internationale 21 (2004), 227-244.

$21 \quad$ Cultural Transfer through Translation: the Circulation of Enlightened Thought in Europe by Means of Translation. Ed. Stefanie STOcкHORST. Amsterdam, New York 2010.

${ }_{22} 2$ The Book of Common Prayer : Studies in Religious Transfer. Ed. Rémy BETHMONT, Aude DE MEZERAC ZANETTI. Special issue of Revue française de civilisation britannique, Paris 2017 ; Le voyage des Républiques anglaises dans l'espace européen aux XVIIe et XVIIIe siècles. Ed. Luc BOROT, Myriam-Isabelle DuCROCQ. Special issue of Philosophical Enquiries. Revue des philosophies anglophones. Paris, 2017.

${ }_{23}>$ Better in France? The Circulation of Ideas across the Channel in the Eighteenth Century. Ed. Frédéric OGÉE. Lewisburg, PA 2005; British-French Exchanges in the Eighteenth Century. Ed. Kathleen HARDESTY, Dorothy MEDLIN. Newcastle 2007; Les idées passent-elles la Manche?: savoirs, représentations, pratiques : France-Angleterre, Xe-XXe siècles. Ed. François-Joseph RugGIU, Jean-Philippe GENET. Paris 2007; Anglo-French Attitudes: Comparisons and Transfers between English and French Intellectuals since the Eighteenth Century. Ed. Christophe CHARLE, Julien VINCENT, Jay Murray WINTER. Manchester 2007; Intellectual journeys: the translation of ideas in Enlightenment England, France and Ireland. Ed. Frédéric OgÉE, John DunKLey, Lise ANDRIES, Darach SANFEY. Oxford 2013. 
The Channel can be understood as a zone of contact and exchange, not just conflict. ${ }^{24}$ The editors of Cultural Transfers: France and Britain in the Long Eighteenth Century have devoted an insightful and historiographically strong introduction to Anglo-French cultural transfers, while recognizing that they adopted a supple understanding of the model since their aims partly differed from the original intentions of the Franco-German team (in particular, their focus was not on the emergence of a national culture). However the book is exemplary of cultural transfer methodology, both in its objects (the three overlapping areas covered being networks and correspondences, journalism, and translations) and in its methodological concern for intermediaries, channels and networks of communications, constraints placed on actors, the impact of imports on the recipient culture, and especially »what new configurations emerged in this process. ${ }^{25}$

Where does the Baltic stand with respect to cultural transfers with Britain? It is virtually absent from the above-mentioned literature that focuses on France and Western Europe mostly. But there have been studies on translation and the circulation of ideas between the Scottish Enlightenment and German thinkers, some of whom lived in the Baltic region. ${ }^{26}$ Herder, in particular, drew on some insights of the Scottish philosophers, and his critique of cosmopolitan modernity was inspired partly by Adam Ferguson as Eva Piirimäe has shown. ${ }^{27}$

On the other hand, interactions between Britain (and especially Scotland) and the Baltic have been studied in three fields, neither of which is primarily concerned with cultural transfer: economic history; Jacobitism; and what may be called the »Northern world «. Economic historians have shown that trade between Britain and the Baltic was brisk, though its share in British overseas trade declined because of the boom of Atlantic exchanges. But the

$24 \quad$ Stephen ConwaY: »Transnational and Cosmopolitan Aspects of Eighteenth-Century European Wars«. In: Cosmopolitanism in Conflict: Imperial Encounters from the Seven Years' War to the Cold War. Ed. Dina GuSEJNOvA. London 2018, 29-54; Renaud MorIEux: The Channel: England, France and the Construction of a Maritime Border in the Eighteenth Century. Cambridge 2016.

${ }_{25}$ Ann ThOMSON, Simon BuRRows: »Introduction«. In: Cultural Transfers: France and Britain in the Long Eighteenth Century. Ed. Ann Thomson, Simon Burrows, Edmond Dziembowski, Sophie Audidière. Oxford, $2010,3$. László KontLer: Translations, Histories, Enlightenments : William Robertson in Germany, 1760-1795. New York 2014.

27 John H. Zамміто: »Die Rezeption der schottischen Aufklärung in Deutschland. Herders entscheidende Einsicht«. In: Europäischer Kulturtransfer im 18. Jahrhundert : Literaturen in Europa - Europäische Literatur. Ed. Barbara SchmidtHaberkamp, Brunhilde Wehinger, Uwe Steiner. Berlin 2003, 113-138; Eva PIIRIMÄE: »Sociability, Nationalism and Cosmopolitanism in Herder's Early Philosophy of History«. In: History of Political Thought 36 (2015), 521-559. 
two areas should not opposed, historians have recently argued: as one set of merchants in London directed operations in both areas, the Baltic, ranging from Sweden and Denmark to Russia, was integrated into the Atlantic economy, a fact which calls for »a unified history of these two busy areas of mercantile endeavour $« .{ }^{28}$ One challenge is to treat the Baltic as more than just a semi-periphery providing raw materials to a richer, more advanced core (to use Immanuel Wallenstein's world-system terminology). The question remains whether, or how, economic integration led to cultural to cultural exchange and homogeneization; but the »Atlanticization« of the North certainly had cultural consequences. One key area has been investigated in depth: anticolonial discourse in Riga and Courland, especially Garlieb Merkel's anticolonial critique of serfdom in Die Letten. Merkel's adaptation of Abbé Raynal's arguments to the Baltic context have been dissected by Thomas Taterka and others who, like Hans-Jürgen Lüsebrink, have self-consciously situated themselves in the paradigms of cultural transfer and entangled history. ${ }^{29}$ Those recent studies, which have brought to light Merkel and other lesser known anticolonial Baltic authors, could be brought into perspective thanks to work on »slavery hinterland «, a concept applying to zones beyond the Atlantic seaboard that were not directly involved in the slave trade yet were impacted by it economically and culturally. ${ }^{30}$ Riga, Petersburgh and the surrounding regions lay in that hinterland, and comparison with other thinkers elsewhere, like Therese Huber in Berlin, could bring out both the originality of Merkel's anticolonial critique and the commonalities of a transnational abolitionism that encompassed the whole of the Baltic seashore and central Europe.

\footnotetext{
28 Åsa EkLUnd, Chris Evans, Göran RYdÉN: »From the Baltic to the Atlantic : British Merchants and the Development of Trade Networks in the Northern Seas during the Eighteenth Century«. In: Spinning the Commercial Web : International Trade, Merchants, and Commercial Cities, c.1640-1939. Ed. Margrit Schulte Beerbühl, Jörg Vögele. Frankfurt am Main; Oxford 2004, 203-215.

${ }_{29} \quad$ Raynal - Herder - Merkel: Transformationen der Antikolonialismusdebatte in der europäischen Aufklärung. Ed. York-Gothart MiX, Hinrich AHREND. Heidelberg 2017 ; Thomas TATERKA: »Humanität, Abolition, Nation, Baltische Varianten des kolonialkritischen Diskurses der europäischen Aufklärung um 1800«. In: MiX, AHREND: Raynal - Herder Merkel, 183-252 ; Hans-Jürgen LÜSEBRINK, »Guillaume-Thomas Raynal und Garlieb Merkel - Reflexionen und Ansätze zu einer transkulturellen Verflechtungsgeschichte«. In: Mix, AHREND: Raynal - Herder - Merkel, 143-158. $30 \quad$ Slavery Hinterland: Transatlantic Slavery and Continental Europe, 1680-1850. Ed. Felix BRAHM, Eve Rosenhaft. Martlesham, 2016.
} 
In addition to trade, another strong area of scholarship is Jacobitism. Specialists have long recognized the presence of a Jacobite diaspora on the shores of the Baltic. ${ }^{31}$ The limelight has been largely thrown on the Jacobites in France and Italy, whose presence in the Jacobite courts at Saint-Germain en Laye and later Urbino and Rome, involved cultural production and consumption of high quality and originality. ${ }^{32}$ Yet there were English, Scottish, and Irish Jacobite courtiers, advisers and spies in the courts of Sweden, Russia, and lesser powers, as well as Jacobite soldiers in their armies. There exists no overall study of a »Baltic« Jacobitism, if only because the Jacobites found themselves in rival, often warring, countries, which considerably complicated their agenda of bringing major Northern powers to support a Stuart restoration. ${ }^{33}$ Jacobitism did entail cultural transfer in the sense that Jacobite emblems, objects and customs (conviviality, toasting) adapted to local circumstances, but the impact of Jacobitism on the outside culture (not just inside Jacobite circles and networks) remains unclear.

One commonality between trade links and Jacobitism is the presence of British, and especially Scottish expatriates on the shore of the Baltic. A whole historiographical field bears on »the Northern World « linking Scotland to Scandinavia and the Baltic. A collection bearing this name at Brill publishing and a number of journals have hosted studies of the Scottish diaspora and its links with the home country and the various societies bordering the Baltic shores. From the Netherlands to Riga, the Scots established a network of enclaves in seaports and further inland, especially in the Polish-Lithuanian Commonwealth, where a whole community of Scottish Calvinists was brought in to form the city of Kedainiai. ${ }^{34}$ Since the 2010s a rich historiography has examined return migration, which has occurred ever since the

31 The Jacobites were the partisans of King James VII of Scotland/II of England who fled to France in the course of the 1688-1689 'Glorious Revolution', taking refuge in France with Louis XIV's backing. James's descendants and their followers (both in the British Isles and in exile abroad) kept up his claim to the throne and mounted two rebellions, in 1715 and 1745-46.

32 Edward Corp: A Court in Exile: the Stuarts in France, 1689-1718. Cambridge 2009; Edward Corp: The Jacobites at Urbino: an Exiled Court in Transition. Basingstoke; New York 2009; Edward CoRP: The Stuarts in Italy, 1719-1766: a Royal Court in Permanent Exile. Cambridge; New York 2011; Loyalty and Identity: Jacobites at Home and Abroad. Ed. Paul Kléber MonOD, Murray PitTock, Daniel SzeCHI. Basingstoke; New York 2010.

33 See however studies of networks like Steve MURDOCH : »Des réseaux de conspiration dans le nord ? Une étude de la franc-maçonnerie jacobite et hanovrienne en Scandinavie et en Russie, 1688-1746«. In: Politica Hermetica 24 (2010), $29-56$.

34 Scottish Communities Abroad in the Early Modern Period. Ed. Alexia GrosJEAN, Steve Murdoch. Leiden; Boston 2005; Rimantas ŽIrgulis, »The Scottish Community in Kèdainiai c. 1630 - c. 1750«. In: MuRdoch, GrosjEAN, Scottish Communities Abroad, 225-248. 
late seventeenth century when second-generation Polish-Scots returned to Scotland. Those studies show »how the process of return shapes the identities of both migrants and the communities to which they come back «. ${ }^{35}$ Studies of the Scottish diaspora have to overcome several obstacles; besides the need for strong language skills needed to navigate several cultural spaces and historiographies, the dispersal of archives and excessive specialization over one particular city or area may preclude perceptions of wider, regional or transnational patterns. ${ }^{36}$ The collections of essays mentioned in this paragraph try to be more than strings of case studies and to generalize results. One new avenue of research is to place migrations in the Northern World in European context, through a comparative approach of the emigrant experience of the Scots, the Irish other Europeans in the early-modern period. ${ }^{37}$

On the basis of this brief review of British-Baltic links, it is possible to identify a few areas which could be usefully complemented by cultural transfer studies. A first question raised is the cultural implications of maritime trade and migrations. In the eighteenth century, the Baltic timber trade was of strategic importance to Britain's navy, and hence its capacity to wage war and survive as an independent nation. ${ }^{38}$ Does it follow from this sustained trade pattern and its geopolitical implications, that cultural transfers did take place, changing Baltic, Scandinavian, or British cultures in the process? »Northern World « research has focused on emigrants' experiences rather than their impact on the receptor culture (with exceptions). The involvement of cultural go-betweens and productions still needs establishing, and one cannot conclude to the existence of anything undergoing transfer on the simple evidence of trade links. A case in point is Steve Murdoch's comparison between Scottish networks in Bordeaux and in the United Provinces from 1670 to 1720. In the late seventeenth century, during the repressive policies of the late Stuart monarchs, and after the Glorious Revolution of 1688-

\footnotetext{
35 D. A. J. MACPhERSON: »The Scots Abroad: Recent Approaches to Migration, Diaspora and Identity«. In: Northern Scotland, 8 (2017), 89.

$36 \quad$ Kathrin ZiCKERMANN: Across the German Sea: Early Modern Scottish Connections with the Wider Elbe-Weser Region, Leiden; Boston, 2013, 235-236.

Lex Heerma van Voss, Sølvi Sogner, Thomas O’Connor: »Scottish Communities Abroad : Some Concluding Remarks «. In: Murdoch, GrosJEAN, Scottish Communities Abroad (= Anm. 33), 375-394.

38 Ragnhild Hutchison: » The Norwegian and Baltic Timber Trade to Britain 1780-1835 and its Interconnections «. In: Scandinavian Journal of History 37 (2012), 578-599; James DAVEY, »Securing the Sinews of Sea Power: British Intervention in the Baltic 1780-1815«. In: The International History Review 33 (2011), 61-184.
} 
1689, the Netherlands were willing »to make a good, symbiotic use of the arrivals « of Scottish political-religious refugees that fled persecution and, after 1689, régime change. Although trade relations were as strong with Bordeaux as they were with Holland, the French seaport never hosted a large Scottish community and was apparently not impacted with the ideology of Scottish Jacobite emigrants, who found little in the way of religion or politics to bind them with the French. The links between Bordeaux and Scotland remained limited to the economic interests of the wine trade that was the original reason for the connection. ${ }^{39}$ It takes a precise case study to establish the existence and exact nature of a transfer. Incidentally Murdoch's comparative analyses bring out the originality of the Dutch case: comparatism should perhaps complement rather than oppose cultural transfer. Such work also suggests that comparative studies of the impact of the Scottish merchant communities in Baltic seaports like Riga would be welcome.

Besides the study of migration and diaspora in the Baltic area, cultural transfer methodology could be applied to the area where it has displayed the most strength, the intellectual history of cultural productions and their circulations as the treatment of Merkel's Die Letten demonstrates. One line of enquiry starts with the identification of cultural intermediaries. Leaving aside the discovery of new ones for the moment, it may be the case that the Baltic dimension has been underappreciated even in the case of well-known figures such as architect William Chambers (1722-1796), who wrote in an autobiographical note: »I was born in Gothenburg, was educated in England, and returned to Sweden when I was 16 years old. I made three journeys to Bengal and China in the service of the Swedish East India Company $\ll^{40}$ Chambers was famous for popularizing the taste for Chinese gardens in Britain, a fashion that was taken up in other countries as an English-style orientalist gardening style. The Swedish background of the expeditions might yield some significant information, and, together with Chambers's study of architecture and gardening in South China, his education

\footnotetext{
39 Steve Murdoch: »The French Connection : Bordeaux’s 〉Scottish Networks« in Context, c. 1670-1720«. In: Scotland and Europe, Scotland in Europe. Ed. Gilles LEYDIER. Newcastle upon Tyne 2007, 26-55.

Quoted in James Harris: »Chambers, Sir William (1722-1796), architect«. In: Oxford Dictionary of National Biography. <http://www.oxforddnb.com/view/10.1093/ref:odnb/9780198614128.001.0001/odnb-9780198614128-e-5083.>
} 
in Paris and Rome, and his success in London, it lends a truly global dimension to the man, his achievements and his writings.

»Below « those famous international (and internationalizing) figures more modest gobetweens - e.g. translators, educators, publishers or journalists - can be identified, if only by starting by a bibliographical search, for instance a search of items in English published in Riga in the eighteenth century. The English Short Title Catalogue ${ }^{41}$ gives only three results but even such a poor yield suggests opportunities for cultural transfer studies.

First comes a quarto sheet by one Andreas Biorkgren advertising An approved balsam for the head, rheumatism, wounds and nerves. I. It recommends itselffor a shot, stab or cut wound. ... This marwelous [sic] balsam is to be had by te [sic] maker Andreas Biorkgren, at Riga, in Smith-Street naer [sic] the townes [sic] steables [sic] (ESTC number T205636). The compilers of the catalogue give a tentative date of 1790 , adding that $»[a] d v i c e$ on dating this will be gratefully received «. There seems to exist only one copy of this small piece (in the Wellcome Library in London), and the author of this article has not seen it. The title, as well as the shaky spelling, raise a series of questions about the readership (the British community in Riga, British sailors stopping in the city, exporters to Britain?); medical discourse and popular beliefs in the curative powers of balsam; the balsam producer's marketing strategy and hence the cultural transfer involved in trade and the sale of a medicine, possibly the Riga black balsam which to this day has become an icon of Latvia.

The other two English-language imprints from Riga are textbooks published between 1792 and 1794 by Johann Georg Rievethal, three volumes of Lectures Intended for the Instruction and Amusement of Young People, Who Apply Themselves to the English Tongue (Riga, J. Fr. Hartknoch, 1792, 1793, 1794), and a slimmer work, which presents itself as a sequel to the lectures, Historical and Moral Miscellanies or a Choice or Interesting Tales, Anecdotes, Curiosities of Nature, Lives of Remarkable Men, Customs of People, and Reflections on Several Important Subjects (Riga, I. Fr. Hartknogh, 1794) ${ }^{42}$ In 1795 Rievethal

\footnotetext{
$41 \quad$ The ESTC is freely searchable at <http://estc.bl.uk/>.

42 The English Short Title Catalogue numbers are N60469 and N66491. The publisher must be the same, though the name is spelt slightly differently.
} 
also published a similar collection of lectures, in French, still with his publisher Hartknoch. ${ }^{43}$ The foreword to the Miscellanies rather blandly promises pedagogical tool for the study of English combining instruction and delight, in classic Horatian fashion. But the choice of extracts is worth commenting, as it introduces to pupils in Riga a medley of stories. Some of which (Spanish tales or Brahmin legends) may be innocuous enough, but, in the context of the tsarist empire in the midst of the French Revolution, other texts have more political bearing, especially the execution of four Protestants in France in 1762, and »authentic memoirs of Alexis Pugatscheff $\ll{ }^{44}$ A study in cultural transfer should focus on Rievethal, his social standing in Riga - the title page of the Miscellanies present him as »instructor at the Cathedral school in Riga « -, his intellectual upbringing and ambitions, and his editorial and pedagogical options. But as Rievethal was one among many, he could also be located within the transnational the network of pedagogues and publishers who circulated, copied, translated and adapted texts. Cultural transfer methodology could help elucidate the Baltic/Latvian reception of »Enlightenment « texts (to put it in very general words, given the unspecialized nature of Rievethal's language teaching); a study of networks cannot be conducted on the basis of Rievethal's publications alone but is dependent on the availability of correspondences and archives. Cultural transfer methodology could help elucidate the Baltic/Latvian reception of $»$ Enlightenment « texts (to put it in very general words, given the unspecialized nature of Rievethal's language teaching); a study of networks cannot be conducted on the basis of Rievethal's publications alone but is dependent on the availability of correspondences and archives.

This essay has tried to sketch out a few possible directions of research on BritishBaltic transfers. It is suggested here that cultural transfer methodology has not been much brought to bear on this field, despite shining exceptions like recent work on Merkel's creative adaptation of French and British anticolonialism. In one sense, however, perhaps the

43 I. G. RIEVEHAL: La ruche, ou lecture amusante et instructive pour la jeunesse. Riga 1793-1795. 3 vols. 44 RIEVEHAL: Historical and Moral Miscellanies, 184-196, 36-46. 
paramount wish of cultural transfer theorists has been granted, in the sense that many historians have resisted the compartmentalization of historical reality along nation-state lines and taken a variety of transnational approaches instead. Relations between Britain and the Baltic could be fruitfully studied by the cultural transfer approach, especially as it provides a spirit and general guidelines rather than a methodological straightjacket, and as it complements rather rivals other approaches (such as comparative studies of British expatriate communities along the Baltic shores and elsewhere, which are a dynamic part of »Northern World« scholarship). Current trends in British historiography favour such studies, in particular approaches in terms of European connections and transfer (and criticism of approaches in terms of opposition between Britain and continental »Others «) and the broadening of the »Atlantic « away from an exclusive focus on North America to encompass continental European »hinterlands $\ll$.

This article could not be complete without an acknowledgement of the importance of the researcher's own location and point of view. The author of this article is a French specialist of Britain; and his historiographical review and resulting suggestions of further studies must be dependent on this position. Writing as an outsider to the field may enable a quicker perception of gaps, or suggestions of studies on the model of what is done in another field. On the other hand, one absolute condition to cultural transfer research is the need for strong language skills; another requirement that may be still more difficult to attain is a familiarity with two (or more) cultures and historiographies. The emphasis on the receptor context in cultural transfer theory means that an excellent knowledge of the receptor culture is fundamental. Possible omissions of publications from researchers in Baltic countries in this article stem from sheer ignorance. The implication is that cultural transfer studies might be best carried out in teams rather than single-handedly. More importantly, and more positively, just as the present study started from French, British (and to a lesser extent German) historiography and tried to apply to the Baltic, conversely researchers based in a Baltic state might wish to study cultural transfers with Britain starting from their historiography, in a process that would yield other results and open up new perspectives. 
Rémy Duthille, Bordeaux 